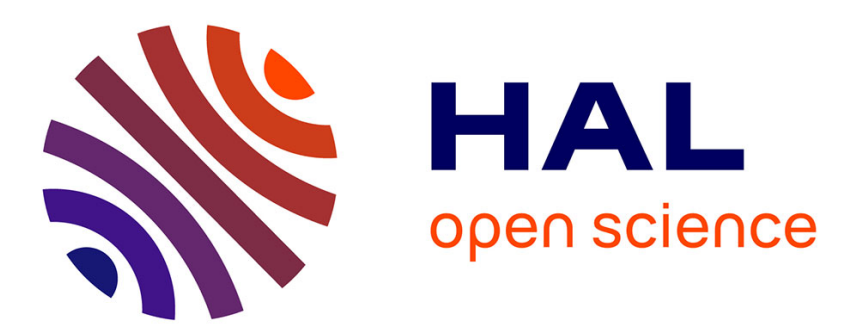

\title{
Creativity, Giftedness and Education
}

Maud Besançon

\section{To cite this version:}

Maud Besançon. Creativity, Giftedness and Education. Gifted and talented International Journal, 2013, 28 (1\&2), pp.149-161. 10.1080/15332276.2013.11678410 . hal-01393542

\section{HAL Id: hal-01393542 \\ https://hal.parisnanterre.fr/hal-01393542}

Submitted on 9 Nov 2016

HAL is a multi-disciplinary open access archive for the deposit and dissemination of scientific research documents, whether they are published or not. The documents may come from teaching and research institutions in France or abroad, or from public or private research centers.
L'archive ouverte pluridisciplinaire HAL, est destinée au dépôt et à la diffusion de documents scientifiques de niveau recherche, publiés ou non, émanant des établissements d'enseignement et de recherche français ou étrangers, des laboratoires publics ou privés. 
Creativity, giftedness and education

\author{
Maud Besançon \\ Université Paris Ouest Nanterre La Défense \\ Laboratoire CHArt (EA4004)
}

Author's address :

Laboratoire CHArt (EA 4004)

UFR SPSE, Bâtiment C

Université Paris Ouest Nanterre La Défense

200 avenue de la République

92001 Nanterre Cedex, France

e-mail : maudbesancon.psy@gmail.com 


\begin{abstract}
In this article, conceptions of creativity in giftedness and their implications for education are reviewed. First, the definition of giftedness is examined taking into consideration the difference between intellectual giftedness and creative giftedness and the difference between potential and talent. Second, the nature of creativity based on the multivariate approach is explored. Third, various measures of creativity are presented. Finally, the effect of different pedagogical methods and the influence of teachers on the development of creativity are examined.
\end{abstract}


The education of gifted children represents an important engagement of a society for its future development. Numerous conceptions of giftedness have been proposed. Most have focused on academic achievement and a superior level of intellectual ability, measured by IQ tests (Feldman, 1982; Lubart, 2006). However, there have been recent calls for an expanded view of giftedness, taking into account multiple facets of cognitive functioning, including creativity (Gagné, 2004; Gardner, 1983; Lubart, 2006; Sternberg, 1985). Professionals who work with gifted students recognize that creativity is a salient issue and creative thinking is often a major part of gifted educational programs. Four issues are examined in this article. First, the differences between intellectual and creative giftedness are addressed. Second, a multivariate approach to creativity is presented. Third, different measures of creativity are examined. Fourth, implications for education are exposed, with attention to the influence of teachers and pedagogical methods.

\section{CREATIVITY, POTENTIAL, TALENT}

Is creativity a part of intelligence and giftedness?

For some, intelligence is viewed as a general capacity (Binet \& Simon, 1905; Huteau \& Lautrey, 1999), others see it as a set of distinct capacities (Gardner, 1983), and finally some propose a system of capacities organized in a hierarchical way (Horn \& Cattel, 1966; Gustaffson, 1984). In each perspective the question of creativity has been raised. For Binet and Simon (1905), imagination is a basic mental function. In their tests, they included a few open-ended items such as generating rhyming words or completing sentences to measure this aspect of intelligence. In the theory of multiple intelligence, Gardner (1983) distinguishes various intellectual abilities organized according to the type of cognitive stimuli. Each 
intelligence involves a particular cognitive content: linguistic, logical-mathematical, musical, spatial, kinesthetic, naturalist, intrapersonal and interpersonal. For Gardner, people may be creative in each of these intellectual domains and the nature of the creative intelligence depends on the domain of activity. Finally, Horn and Cattel (1966) make a distinction between fluid intelligence and crystallized intelligence. Fluid intelligence is the capacity for context-independent reasoning whereas crystallized intelligence is the use of acculturated, context-dependent learning. Creative intelligence involves both aspects of intelligence. Indeed, the search for new ideas relies on analogical thinking, evaluation and deductive reasoning; for crystallized abilities, domain-specific knowledge must be applied to select which information is relevant to understand and solve the problem.

Thus most conceptions of intelligence suggest that creativity must be taken into account. However, intelligence tests almost never measure creativity. The first studies concerning gifted children focused on intellectual capacities. Indeed, one of the first measurements used to identify gifted children was the Intelligence Quotient (IQ) equal or higher than 130 (Gowan, 1971). The use of IQ to identify gifted children has limits. The results with such tests (1) provide a measure of the success of the pupil at a given moment, (2) do not study talents which one could observe apart from academic success (Mulhern, 2003).

Many authors consider that creativity is a basic capacity for any form of high potential. In particular, Renzulli $(1979 ; 1986)$ postulates that high potential in any field of activity stems from three components: (1) above-average general intellectual capacities, as measured by traditional tests of intelligence; (2) engagement in the task, which includes factors such as enthusiasm, interest, perseverance, eagerness, openness to criticism; and (3) creativity which includes fluency, flexibility and originality of thought, openness to new experiences, curiosity, risk taking and aesthetic sensibility. 
Gagné (1983) has questioned this model. One of the issues is whether creativity is a systematic component of high potential for all fields or sub-fields of endeavor. For example, in the field of dance, a choreographer must be creative in order to propose new sequences, a new choreography, whereas the dancer, interprets this choreography; so the dancer is not necessarily creative, rather expressing best what is required by the choreographer. In sports, there is the example of Fosberry who invented a new way of executing the high jump; a creative accomplishment. However, most gifted and talented athletes who compete in the high jump for field and track seek to execute it as well as possible without any concern for creativity.

According to Maker (1993), intelligence and creativity are capacities that play different roles in the phenomena of high potential depending on the nature of the problem with which the individual is confronted. Different types of problems emphasize either intelligence or creativity. The problems that involve creativity tend to have a vague formulation, require a solution to be invented, and often do not have a single "right" answer. This position is consistent with the view that the distinction between intelligence and creativity is an artificial one; perhaps, there is a continuum from intellectual to creative giftedness which is more or less pronounced depending on the domain and the nature of the task in the domain (Runco \& Albert, 1986). We will now examine the differences between potential and the realization of this potential.

\section{Differences between potential and talent}

It is one thing to have potential and another to express it, to put it to use effectively. For example, certain studies of children with a high IQ (Peters, Grager-Loidl \& Supplee, 2000; Reis \& McCoach, 2002) found that some do not show the expected academic performance. Rather, these children underachieve, showing low or failing grades, and clearly do not express their potential. According to Gagné (1983), the gift corresponds to a 
competence that is definitely higher than average in one or more fields of skills. Talent is defined as a performance definitely higher than average in one or more fields of human activity. These definitions highlight that a person with talent is necessarily a gifted one. On the contrary, any child with high potential does not necessarily express this "gift". For Gagné (1983), motivation makes it possible to transform the gift into talent.

The phenomenon of "underachievement", the gap between giftedness and talent, is not limited to academic performance. Olszewski-Kubilius (2000) highlights the gap between children's giftedness and their creative productiveness; different kinds of factors explain this discontinuity - environmental conditions in childhood and stable individual characteristics such as motivation and personality. However, Kim (2008) has questioned the possible link between underachievement and creativity as certain characteristics of children showing underachievement are similar to those of highly creative children. In the next section, the nature of creativity and the factors which can influence it are described.

\section{THE NATURE OF CREATIVITY}

\section{Definition of creativity}

Creativity can be defined as the capacity to produce something new and adaptive within the constraints of a given situation (Lubart, Mouchiroud, Tordjman \& Zenasni, 2003). Thus a creative production must be original, at least to some extent. Is this creative capacity general or specific to each field? Although the debate is not settled, (see Lubart \& Guignard, 2004), many authors support a rather domain-specific modular conception (Gardner, 1983; Feist, 2004). For example, a child may have a high creative capacity in the scientific field (mathematics, sciences) but may have difficulty inventing a story. Another child may be creative in verbal tasks (such as inventing a story) but have difficulties making an original 
drawing. Thus, creative abilities can differ depending on the field. These differences in creative performances can be understood within the multivariate approach.

\section{Multivariate approach}

According to Sternberg and Lubart (1995), different factors contribute to creative potential. The differences observed between individuals result from a combination of cognitive, conative and environmental factors (Lubart, Mouchiroud, Tordjman \& Zenasni, 2003).

\section{$\underline{\text { Cognitive resources and development }}$}

Cognitive factors refer to knowledge and information-processing abilities that facilitate inventive thinking. Creative performance is partly domain specific because individuals do not have the same level of knowledge in every field. In addition to knowledge, different intellectual abilities are required in the creative process, such as flexibility, divergent and convergent thinking (see Sternberg \& Lubart, 1995).

Flexibility refers to the ability to find varied solutions to a problem, to change ones' approach to solve it and to understand it from different angles (Georgsdottir \& Lubart, 2003). Divergent thinking is the ability to generate many different ideas from a given stimulus or starting point. According to Guilford (1950; Lubart \& al., 2003), divergent thinking is an essential ability for creative achievement. Empirically, the more ideas generated, the greater the chance to find at least one that is original. Creativity requires also convergent thinking in order to wean out the best ideas and improve them. The combined use of both divergent and convergent thinking seems essential.

\section{$\underline{\text { Conative resources and development }}$}

Conative factors refer to traits of personality and to motivation. Some traits of personality, such as risk taking, openness, tolerance of ambiguity, are important to develop original thinking (Lubart \& al., 2003). For example, in many schools, most of students do not 
take initiatives because the teacher decides what students should do. On the contrary, in Freinet's alternative pedagogy (described in detail later in this article) children can choose their activities. Moreover, children can suggest others activities like theatre. Sometimes, if a group of children wants to engage in a particular project, they have the possibility. For example, two girls in the $5^{\text {th }}$ grade have suggested organizing a dance class; they proposed this to others, formed a group, prepared by themselves a choreography and finally, at the end of the year presented their show.

Motivation corresponds to the energetic strength with which an individual engages in performing a task. Two types of motivation are often compared for creativity (Amabile, 1996): intrinsic and extrinsic motivation. Intrinsic motivation comes from the inner needs of individuals such as curiosity drive, it focuses on the task and the enjoyment derived from solving the problem. Alternatively compensations, like material goods, money, award or social praise generate extrinsic motivation. Results of most research show that intrinsic motivation is positively associated with creative performance. A relationship between creativity and extrinsic motivation also exists but appears less obvious, varying according to the circumstances of the task and moderating traits of the individual (Amabile, 1996; Baer, 1998; Collins \& Amabile, 1999).

\section{$\underline{\text { Environmental factors }}$}

Environment influences not only the development of creative capacities but also the various forms that creative expression may take. The environmental influence occurs in different spheres: in the family, in the school or work environment and in the cultural context in which the person evolves. These various environments are embedded in each other.

The familial environment provides the cognitive and emotional bases for the development of creativity. Simonton (1984) showed that a familial environment full of cultural stimulation (books, arts...) favors creative development. Lautrey (1980) observed a 
link between children's intellectual capacities and family structure; in more recent research, children living in families with "flexible" rules (for example, children must to go to bed at 8p.m. if they have school in the morning; but on the week-end, they can stay up later to see television programs) for governing children's activities showed higher levels of creative thinking than did children who lived in families with rigid rules (for example, children must always go to the bed at 8p.m. regardless of special circumstances) (Lubart \& al., 2003).

School and later professional environments have each an important impact on creative expression. Indeed, under some conditions, these environments can stimulate creative behavior whereas in other cases they hinder it. For example, aspects of a creative climate in work settings include (Crespo, 2004): time for ideas, freedom to create, humor, discussion, absence of conflict, openness, risk-taking, support for innovation and tolerance of differences. Concerning the school environment, the study of the development of creativity in children shows periods of stagnation and sometimes temporary decline of average levels of creative performance (Torrance, 1968). The majority of the explanations for these results refer to the school environment because these slumps are found mainly at the time when children change school cycles (e.g., move from kindergarten to first grade) (Torrance, 1968). As we will see in a later section of this article, many studies concerning gifted children and schooling suggest the importance of the school environment for the development of talent (Baldwin, 1987; Kim, 2008; Landrum \& Ward, 1993).

Finally, culture refers to the set of thoughts, traditions, values and symbols that structure the way in which a group of individuals interacts with the social and physical environment. The values transmitted through the social environment promote or inhibit creativity. This promotion depends on the field and on the culture. $\mathrm{Ng}$ (2001) suggested that if there is a difference in creative products between occidental and oriental cultures, it seems to be due, at least partly, to the dimension of individualism and collectivism. Indeed, there is a 
link between individualism and intrinsic motivation, which was already mentioned as an important factor for the creative product.

The combination of these different kinds of factors influences creative potential and its' expression in different fields. It is possible to evaluate psychological profiles based on these factors to measure an individual's creative potential. Consider in the following section, different kinds of tests used often to identify creative potential.

\section{MEASURES OF CREATIVITY}

Numerous tools have been proposed to evaluate creativity. We will first examine divergent thinking tasks, then integrative-thinking tasks, questionnaire measures and finally parent and teacher appreciations.

These different kinds of measures of creativity can be categorized into two groups: measures of creative potential and measures of creative achievement. The first one evaluates creative giftedness (divergent thinking, productive-integrative tasks and out-of-school activity questionnaires). Evaluations by teachers or parents can us inform about both creative potential and actual creative achievement.

Divergent thinking tasks

Consider three tasks that come from the Torrance Tests of Creative Thinking (TTCT, 1976). These tasks evaluate the ability to generate many ideas from a given stimulus with verbal and graphic modes of expression. For example, in the "New uses of a cardboard box" task, we explain to children that a cardboard box can be used in many ways rather than being thrown away. Children must give as many original ideas as possible in ten minutes. In the "Improvement of toy" task, children must give as many ideas as possible to improve a stuffed animal. They have ten minutes. Even if proposed changes are costly, they can give all 
propositions. In the "Parallel lines" task, children must make as many drawing as possible based on sets of parallel lines.

For these kinds of tasks, different scores are calculated: fluency, flexibility and originality. For the graphic task, there is also an elaboration score. Fluency corresponds to the number of ideas given. Flexibility is the number of categories to which ideas belong. Originality is the statistical rarity of the ideas. Finally, elaboration, for the graphic task, is the capacity to develop and embellish the basic drawing. The score depends on the number of details used to develop the basic idea.

It is important to note that divergent thinking is only one part of creativity. So if a child obtained a high score in a divergent thinking task, he or she is not necessarily creative. However, it is easy to evaluate divergent thinking and the majority of indices are objective. So many studies use these kind of tasks.

\section{Productive (or integrative) tasks}

In contrast to divergent thinking tasks, productive integrative tasks require the conception and development of an idea. We will examine sample verbal and graphic tasks.

In one verbal creativity task, a story title is proposed, such as "the centipedes'sneakers" (Lubart \& Sternberg, 1995). From the title, each child must generate and then tell aloud a short story. The story is recorded and transcribed. Every story is then evaluated by judges who each give a score between 1 (not creative at all) and 7 (very creative), and an average judgement score is calculated for each production. This consensual evaluation of creative productions using adult judges has been widely used (Amabile, 1996).

In a graphic creativity task, either a topic, such as "tension", or a set of diverse objects is proposed (Lubart \& Sternberg, 1995). The child can complete the drawing as he or she wants but must center the work on the provided stimuli. To evaluate the creativity of the drawings, judges evaluate the drawings on a scale of 7 points, as for the stories $(1=$ not 
creative at all; $7=$ totally creative), and a consensual score is calculated for each drawing. It is important to have several judges, to reduce the subjectivity of the criteria employed. Indeed, usually each judge evaluates the production based on his or her own experience and criteria. Another possibility for judges is to propose several detailed criteria and each criterion is given points according to the rarity of the proposal in the population. This kind of task allows an evaluation of children's capacity to produce something creative upon an external demand and is best considered a measure of creative potential.

Evaluation of Potential for Creativity (EPoC, Lubart, Besançon \& Barbot, 2011)

The Evaluation of Potential for Creativity (EPOC; Lubart, Besançon \& Barbot, 2011) is an up-to-date measurement-tool for children. The development of EPoC is based on two important ideas: first, it is possible to categorize the numerous micro-processes involved in the creative potential into two main sets, called divergent-exploratory processes, and convergent-integrative processes (Lubart, Besançon \& Barbot, 2011). Divergent-exploratory mode of thinking refers to the process of expanding the range of solutions in creative problem solving and includes factors such as flexibility, divergent thinking, selective encoding, which are supported by personality traits, such as openness to experiences and intrinsic task-oriented motivation. Convergent-integrative thinking refers to the activity of combining elements in new ways (including associative thinking, selective comparison and combination allowing a synthesis of various heterogeneous elements to converge into a unique, original production) which are supported by conative factors such as tolerance for ambiguity, perseverance, risk taking, and achievement motivation. Second, as creativity is relatively domain specific, it is important that measures of creative potential take into account the domain of creative expression. Consequently, EPOC measures both sets of microprocesses (divergentexploratory and convergent-integrative, as opposed to previous measurement tools that typically measure a single component), based on diverse domains of expression, whereas the 
previous approaches of creativity measurement had rather a generalist approach (tending to generalize the observed results to any domain of creative expression).

EPoC includes two alternative forms (Form A and Form B) so that users can assess the progress made by children. Each of EPoC's forms is composed of eight subtests which measure both the two types of thinking and two application domains (verbal and graphical). Thus, for each child, there are four measures of creative potential: Divergent-Exploratory Thinking in the Graphic domain (DG), Divergent-Exploratory Thinking in the Verbal domain (DV), Convergent-Integrative thinking in the Graphic domain (IG), and ConvergentIntegrative thinking in the Verbal domain (IV). Results are interpreted in terms of efficiency and creative potential style, yielding an EPoC profile. These styles emphasize an individual's "preference", related to the likelihood to perform well in a particular domain (e.g. high score in DG and IG, suggesting a "preference" for the graphic domain across processes) or a specific mode of thinking (e.g. high score of IG and IV, suggesting a "preference" for the Convergent-integrative thinking mode across domains). These EPoC profiles thus provide useful insights to tailored creativity-based educational programs aiming to guide the development of creativity appropriately, or in a diagnostic perspective (e.g. for the detection of children with high creative potential in the four EPoC indexes).

To summarize, EPoC offers a creativity assessment that combines an approach by domain of creative expression and by mode of thinking, in order to capture the diversity of creative abilities of children. This up-to-date approach thus provides a broader vision of creative potential in children and proves useful as a monitoring tool to guide the development of creativity.

\section{Questionnaires of creative activities}

Different kinds of questionnaires exist. Notably, some extrascholastic-activity questionnaires measures related to creativity. Milgran \& Hong (1999) developed and used a 
questionnaire (Tel-Aviv Activities Inventory) to evaluate the achievement in out-of-school activities in art, science, literature, and music. Children indicate their activities and if they have actually created something. This type of questionnaire measures the implication of children in several activity domains and the extent to which they engage in creativity relevant activities in these fields.

These questionnaires offer a comprehensive idea of children's creativity-relevant work in different domains. However, the potential biases of self-report instruments may influence the data obtained.

\section{Evaluation by parents or teachers}

A last method often used to evaluate creative performance relies on parent and teacher ratings, indicating the extent to which children are creative at home or in school. These types of evaluation are potentially rich because they are based on different moments of observation. Notably, teachers can compare children who are in the same class. However, this evaluation can again be subject to bias, such as social desirability or halo effects in which creative ability is mixed with overall academic performance evaluation (see Noizet \& Caverni, 1978).

\section{CREATIVITY AND EDUCATION}

In the school system, three elements are interrelated: students, teachers and knowledge. These three elements form a teaching triangle which can be organized in many ways (Pelpel, 2002). A teaching method is a specific way to organize relations between the pupils, the teacher and knowledge. First, we will examine the influence of children, then different methods for educating the gifted child. Finally, we will study the specific influence of teachers on creative development. 


\section{Influence of children's characteristics}

Diverse characteristics influence student achievement, including learning styles. (Dunn \& Dunn, 1993; Gregorc, 1982; Wintkin and Goodenough, 1981). For Dunn and Dunn (1993) environmental, emotional, biological, physical and psychological characteristics contribute to a student's learning style (Dunn \& Griggs, 1995). In one study, Karwowski (2008) examined students characteristics by preferences for a rational or an intuitive style. Rational-thinkingstyle-oriented students were significantly more conformist and less inclined towards a creative, heuristic behavior compared to those preferring the intuitive style. However, preference for the rational-thinking style was correlated significantly with school grades. In another study, Karwowski, Lebuda, and Wisniewska (2008-2009) found relations between stylistic measures, creativity and school performance, with results varying for public and private schools

Research indicates in general that students and trainees learn effectively with a teaching pedagogy that matches their learning style preferences (Lee \& Li, 2008; Zhang, 2008). In the next session the influence of different pedagogies is examined.

\section{Influence of different kinds of pedagogies}

Numerous studies have examined the influence of the school environment on gifted children.

In traditional pedagogy, teachers generally use a method centered on their own role in the class. The teacher has complete control: he or she has the knowledge and knows how to transmit it. This method is founded on the performance of the teacher, which can be evaluated by an inspector. In this pedagogy, when children stray from the prescribed method or idea, teachers tend to put the pupils back on the right track. The teacher plays the role of the expert. Development of creativity is not a main objective. Additionally, large classes require that certain norms be maintained to allow the class to advance. The majority of teachers help 
children to follow the rules correctly. Consequently, children do not tend to practice taking risks and being independent. Pupils learn to depend on their teachers and to follow the system's norms.

However, autonomy and risk taking are important for creativity. For example, risk taking is inherently involved in creative thinking and production because one must break from what is known and comfortable, and move in a new direction. There is potential for success but failure may occur, with an idea that does not solve the problem well and/or is criticized by others. In a series of studies, Clifford (1988) examined the development of risk taking in children aged from 8 to 12 . Clifford asked children to choose a problem in a list in which the difficulty of each problem was indicated for each school level (third grade, fourth grade and so on). Results show that on average children chose problems that were relatively easy, corresponding to a lower school level than their own. The difference between the real grade level of children and the grade of problem chosen was greater and greater with age. With school years, children took less and less risks because they were afraid of failure. This attitude may promote good grades but does not foster creativity. On the contrary, generally in alternative pedagogy, teachers do not use grades. So children are less afraid of taking risks. Moreover, teachers allow children to choose their own activities.

Furthermore in traditional school, concerning cognitive abilities, mainly "right-answer" thinking is solicited. In fact, when a student is confronted with a problem, only one solution is generally possible. For example, teachers ask "what is the result of 7+7?"; and expect one right response "14". However, teachers could ask "what makes 14?" For this question, different responses can be given, thereby involving divergent thinking. These two types of exercises differ on the nature of problem (Maker, 1993): the first is closed whereas the second is more open, on a continuum from well-formulated problems with one right solution (closed problem) to problems that have less constrained formulations with various possible solutions 
(open problem) (Getzels \& Csikszentmihalyi, 1976). In closed problems, all is known to the teacher, and the child does not know the response. On the contrary, for open problems, all the possible responses are not known and the formulation allows children to adopt different approaches and find several responses.

In classical pedagogy, pupils are often in competition. Indeed, with grades, children tend to compare their performance. This competition can develop perseverance and provide certain forms of motivation. Perseverance is important in creativity because the answer is not always easy to find. However, according to Conti and Amabile (1999), intrinsic motivation is most important for creative activity. Whereas extrinsic motivation from competition may contribute to creative production as well, it is intrinsic motivation that is most conductive to creativity.

In summary, classical pedagogy brings some elements, useful for the development of creative capacities, such as competition, motivation, convergent thinking and knowledge. However, as noted, classical pedagogy fails to develop fully the components needed for creativity, or is even antithetical to it in certain ways (Besançon, Lubart \& Barbot, in press; . Loi and Dillon (2006) propose a conceptualization of educational environments to develop creative abilities in children. For them, it would be important to foster certain intellectual abilities such as transference and synthesis in cross-disciplinary situations. Moreover, some gifted students, who are characterized by faster learning and by a desire for independence (Mulhern, 2003), are bored in traditional classrooms (Kanevsky \& Keighley, 2003).

Some researchers and educators have sought a better school environment for gifted students (Coleman, 2003). Different methods of schooling for gifted children (grouping, enrichment programs, pullout programs and acceleration) have been tested and each one has its partisans (Lautrey, 2004). Consider each of these methods in terms of its relevance to creativity. 
For the grouping option, children can be placed in groups according to their performance. Although this may seem to be a coherent approach, this type of program has been found to influence negatively the self-esteem of students who had an outstanding position in their original class and become, with this method, average or below average (Kulik et Kulik, 1992). Another possibility is to group children of different grades only for one subject according their performance. In this case, creativity is not necessarily fostered: children are grouped according their performance in general fields and not according to creativity.

Enrichment programs and pullout programs propose to gifted children additional activities because they acquire the regular lessons more easily and quickly. There are various activities: development of creativity, problem solving, and development of individual projects. These programs can occur during the holidays (enrichment program) or during the school week, at certain hours (pullout programs). The effect of pullout programs suggests that school performance is sometimes enhanced and that performance on specific activities is better but the difference with other, control group children is not significant (Vaughn, Feldhusen, \& Asher, 1991). In this type of activity, it is easier to improve creativity because there can be a focus on divergent thinking which is an element for creativity. Although certain factors can be improved and contribute to creative giftedness, it is not enough to focus only on certain abilities such as divergent thinking because as we indicated, creativity is influenced by a combination of several factors.

Acceleration allows gifted children to accomplish in a reduced time frame the regular school program; for example, children may follow a three-year program in two years. In this type of program, there are no discontinuities: gifted children cover the entire program during less time. On the contrary, when children skip a grade, there is a discontinuity and they do not 
study the entire program. In accelerated learning, creativity is not usually part of the curriculum, so children do not develop it.

Beyond classic approaches to gifted education, there is the possibility of alternative pedagogies. Indeed, several pedagogies (Montessori, Freinet, Steiner, Decroly, Ferrière) which emerged during the beginning of $20^{\text {th }}$ century are centered on both on content and on pupils' action. Teachers have knowledge and transmit it, but children must actively seek to acquire this knowledge and integrate it. For example, Montessori (1992) suggested that to learn to read, pupils should learn to recognize letters actively, both by sight and with their hands: they move their fingers on letters made in different textures. Teachers bring the material (knowledge) but children adapt it to themselves. For Freinet (Peyronie, 1999), individualized learning through a series of exercises that students accomplish at their own pace is considered important. In classical pedagogy, the whole class moves together; in alternative pedagogies, an individualized pace is possible. If children have a problem, the teacher is there to help them. So, the teacher is mainly a guide, facilitating for children their search for knowledge.

To identify clearly the best practices for educating creative gifted children, it would be necessary to compare all methods in the same study. In any case, there is agreement that it seems to be important to privilege individualized learning. As this proposition exists since the beginning of the $20^{\text {th }}$ century with Montessori and Freinet, introducing this approach in the educative system for gifted would not be totally original! (Mönks \& Mason, 2000). In addition to pedagogical orientation and different methods for educating the gifted child described here, the characteristic of the teacher who implements a pedagogy is important, and this point is treated in the next section. 


\section{Influence of teachers}

Some studies have examined the influence of teachers on children's creative performance. Indeed, teachers' attitude, beliefs and classroom practices influence the development of creativity, notably in elementary school where children are confronted with the same teacher throughout the day. Wentzel (1993) examined the conception of American teachers: for them, an ideal student is a child who follows instructions, keeps quiet and does not ask many questions. Furthermore, a study of Finnish school teachers found a conception of the ideal pupil as honest, broad-minded, valuing self-respect, family security, true friendship and meaning in life (Verkasalo, Tuomivaara \& Lindeman, 1996). A study of Nigerian teachers showed that they valued pupil characteristics such as industry, sincerity, obedience, courtesy, consideration, self-confidence, and health (Ohuche, 1987). Other studies in Germany, Greece, India, the Philippines, Turkey, and the United States have shown that teachers favor quiet, conforming behaviors rather than intellectually provocative ones, which may question the teacher's authority (Fasko, 2002; Strom \& Strom, 2002). So these attitudes promote submission and conformism, which are adapted to disciplined school behavior but not creative behavior which thrives on curiosity and independence (Cropley, 1994; Sak, 2004; Wentzel, 1993). Newton and Newton (2010) explored teachers' conception of creative thinking in primary school science. These results show that teachers' conceptions tend to be narrow, focusing on practical, fact-based investigations. Although teachers are often encouraged to support creativity, their notions of how to accomplish this within specific school subjects may be inadequate. Thus, teachers may not recognise opportunities for involving creativity.

Working with teachers on their attitudes towards creative behaviors in the classroom is therefore important as teachers are in a privileged position to stimulate or stifle creativity. Teachers' attitudes and values are learned and constructed over time. For current teachers 
these attitudes started to develop, probably, when teachers were themselves primary school students and then were confirmed during teacher training. It is important in teacher training and in-service programs to help teachers recognize what attitudes/values they have and to see the effects of these on students' learning. Teachers must be open to the propositions of children, allow failure, and help pupils to overcome failures and frustration by supporting perseverance in their work. Moreover, by favoring independent learning (each child works at his or her own speed) as well as cooperative learning between children (grouping children to do a particular task), teachers foster the development of creativity (Cropley, 1997). Moreover, for Sternberg (2003), teaching in ways that encourage creativity could also improve school performance in general.

Thus, there is an interaction between the characteristics of gifted children, teacher's characteristics and the school pedagogical environment. So, not only the pedagogy but teachers also play a crucial role in fostering each component of creativity.

\section{DISCUSSION-CONCLUSION}

We have seen that creativity is an important component for giftedness. Some authors think that creativity is the highest form of giftedness (Runco \& Albert, 1986). Different measures of creativity exist to identify creative potential and creative achievement. If we use these techniques, we can begin to differentiate the academically gifted children from creatively gifted ones. Creativity needs to be valued at least as much as knowledge acquisition. Thus creativity needs to assessed and recognized through project work as part of school performance. Pedagogical practice is very important to improve creative potential or achievement in children. Indeed, schools can provide an environment that specifically values creative thinking, recognizes it in students and promotes it through teachers' behaviors in the classroom. 
Maker \& Nielson (1995) have proposed the main features that must be modified to develop creative behaviors in the classroom. Notably, a school environment that favors creative giftedness is characterized by research of excellence, development of creativity, critical thinking, "real" problems, independence, individualized learning, encouragement of risk taking, and relatively less structured learning time compared to traditional classrooms. Teachers are informed and conscious of these principles, but their application can be difficult (Sak, 2004). Teachers need to be educated to understand creative development and ways in which creativity can be fostered or inhibited by school practices. Teachers need to be sensitized to creativity issues which are rarely part of their teacher training or priorities. If the formation of future teachers includes such information (about various techniques and the environment to improve creativity), application of such methods could be facilited (Csikszentmihalyi \& Wolfe, 2000). Moreover, alternative pedagogical methods exist since the beginning of the $20^{\text {th }}$ century but few teachers use them; empirically the effects of these pedagogies on creativity, in particular for gifted children in school remain to be studied 


\section{REFERENCES}

Amabile, T.M. (1996). Creativity in context. Boulder, CO: Westview.

Baer, J. (1998). Gender differences in the effects of extrinsic motivation on creativity. Journal of Creative Behavior, 32(1), 18-37.

Baldwin, A.Y. (1987). I'm Black but look at me, I am also gifted. Gifted Child Quarterly, 41(4), 180-185.

Besançon, M., Lubart, T. \& Barbot, B. (in press). Creative Giftedness and educational opportunities. Educational \& Child Psychology, 30(2), 79-88.

Binet, A., \& Simon, T. (1905). Méthodes nouvelles pour le diagnostic du niveau intellectuel des anormaux [New methods for diagnosing the intellectual level of abnormal persons]. L'Année Psychologique, 11, 191-244.

Clifford, M.M. (1988). Failure tolerance and academic risk-taking in ten- to twelve year old students. British Journal of Educational Psychology, 58(1), 15-27.

Coleman, L.J. (2003). Gifted-child pedagogy : Meaningful chimera ? Roeper Review, 25(4), 163-164.

Collins, M.A., \& Amabile, T.M. (1999). Motivation and creativity. In R.J. Sternberg (Ed.), Handbook of Creativity (pp.297-312). Cambridge : Cambridge University Press. 
Conti, R., \& Amabile, T.M. (1999). Motivation/Drive. In M.A. Runco \& S.R. Pritzker (Eds), Encyclopedia of creativity (Vol.2, pp.251-259). San Diego, CA : Academic Press.

Crespo, M.L. (2004). Construction of a creative climate measure instrument in organizations. Estudos de Psicologia, 21(2), 91-99.

Cropley, A.J. (1994). More ways than one: Fostering creativity. Norwood, NJ: Ablex.

Cropley, A.J. (1997). Fostering creativity in the classroom: General principles. In M.Q. Runco (Ed.). Creativity Research Handbook (pp.83-114). Cresskill, NJ: Hampton Press.

Csikszentmihalyi, M., \& Wolfe, R. (2000). New conceptions and research approaches to creativity: Implications of a systems perspective for creativity in education. In K., Heller, F.J. Mönks, R.J. Sternberg, \& R.F. Subotnik (Eds.). International handbook of giftedness and talent (pp.81-93). Oxford: Elsevier Science.

Dunn, R., \& Dunn, K. (1993). Teaching secondary students through their individual learning styles: practical approaches for grades 7-12. Needham Heights, MA: Allyn and Bacon.

Dunn, R., \& Griggs, S. (1995). A meta-analytic validation of the Dunn \& Dunn model of learning-style preferences. Journal of Educational Research, 88(6), 383-393. 
Fasko, D. (2002).Creativity in the schools: What's going on ? Research in the Schools, $9(2), 15-21$.

Feist, G. (2004). The evolved fluid specificity of human creative talent. In E.L. Grigorenko \& R.J. Sternberg (Eds.), Creativity: from potential to realization (pp.57-82). Washington: American Psychological Association.

Feldman, D.H. (1982). A developmental framework for research with gifted children. In D.H. Feldman (Ed.). New Directions for Child Development: Developmental Approaches to Giftedness and Creativity (pp.31-45). San Francisco: Jossey-Bass.

Gagné, F. (1983). Douance et talent: deux concepts à ne pas confrondre. [Gidtedness and talent : two concepts to not be confused]. Apprentissage et Socialisation, 6(3), 146-159.

Gagné, F. (2004). Transforming gifts into talents: the DMGT as a developmental theory, High Ability Studies, 15 (2), 119-147.

Gardner, H. (1983). Frames of mind: The theory of multiple intelligences. New York: Basic Books.

Georsgdottir, A., \& Lubart, T.I. (2003). La flexibilité cognitive et la créativité: une approche développementale, différentielle et expérimentale. [Cognitive flexibility and creativity : a developmental, differential and experimental approach]. Psychologie Française, 48(3), 29-40. 
Getzels, J.W., \& Csikszentmihalyi, M. (1976). The creative vision: A longitudinal study of problem finding in art. New York: Wiley.

Gowan, J.C. (1971). The Relationship between creativity and giftedness. Gifted Child Quarterly, 239-243.

Gregorc, A.F. (1982). An adult guide to style. Columbia, CT: Gregorc Associates, Inc.

Guilford, J.P. (1950). Creativity. American Psychologist, 5, 444-454.

Gustaffson, J.E. (1984). A unifying model for the structure of intellectual abilities, Intelligence, 8, 179-203.

Horn, J.L., \& Cattel, R.B. (1966). Refinement and test of the theory of mind and crystallized intelligence. Journal of Educational Psychology, 57, 253-270.

Huteau, M., \& Lautrey, J. (1999). Evaluer l'intelligence [Evaluate intelligence]. Paris: Presses Universitaires de France.

Kanevsky, L., \& Keighley, T. (2003). To produce or not to produce? Understanding boredom and the honor in underachievement. Roeper Review, 26(1), 20-28.

Karwowski, M. (2008). Giftedness and intuition. Gifted and Talented International, 23(1), 115-124. 
Karwowski, M., Lebuda, I., \& Wisniewska, E. (2008-2009). Creative abilities and styles as predictors of school success. Gifted and Talented International, 23(2)-24(1), 119127.

Kim, K.H. (2008). Underachievement and Creativity: are gifted underachievers highly creative? Creativity Research Journal, 20(2), 234-242.

Kulik, J.A., \& Kulik, C.-L.C. (1992). Meta-analytic findings on grouping programs. Gifted Child Quarterly, 36(2), 73-77.

Landrum, M.S., \& Ward, S.B. (1993). Behavioral assessment of gifted learners. Journal of Behabioral Education, 3(3), 211-215.

Lautrey, J. (1980). Classe sociale, milieu familial, intelligence [Social classe, familial environnent, intelligence]. Paris : PUF.

Lautrey, J. (2004). Les modes de scolarisation des enfants à haut potentiel et leurs effets. [Modes of schooling of gifted children and their effects]. Psychologie Française, 49, $337-352$

Lee, L.-Y., \& Li, C.-Y. (2008). The moderating effects of teaching method, learning style and cross-cultural differences on the relationship between expatriate training and training effectiveness. The International Journal of Human Resource Management, 19(4), 600-619. 
Loi, D., and Dillon, P. (2006). Adaptative educational environment as creative spaces. Cambridge Journal of Education, 36 (3), 363-381.

Lubart, T.I. (Dir.) (2006). Enfants exceptionnels. Précocité intellectuelle, haut potentiel et talent. [Exceptional children : precocity, high potenial and talent]. Paris : Bréal.

Lubart, T., Besançon, M. \& Barbot, B. (2011). Evaluation du Potentiel Créatif (EPoC). [Evaluation of Potential Creativity].Paris: Hogrefe France.

Lubart, T. \& Guignard, J-H. (2004). The generality-specificity of creativity: A multivariate approach. In E.L. Grigorenko \& R.J. Sternberg (Eds.), Creativity: From potential to realization (pp.43-56). Washington: American Psychological Association.

Lubart, T., Mouchiroud, C., Tordjman, S., \& Zenasni, F. (2003). Psychologie de la créativité. [Psychology of creativity]. Paris: Armand Colin.

Lubart, T.I., \& Sternberg, R.J. (1995). An investment approach to creativity: Theory and data. In Smith, S. M., Ward, T. B., Finke, R. A. (Eds.), The creative cognition approach (pp. 271-302). Cambridge, MA, US: The MIT Press.

Maker, J. (1993). Creativity, Intelligence, and Problem Solving: A definition and design for cross-cultural research and measurement related to giftedness. Gifted Education International, 9, 68-77. 
Maker, C.J., \& Nielson, A.B. (1995). Curriculum development and teaching strategies for gifted learners. $2^{\text {nde }}$ ed. Austin,TX: Pro-Ed.

Milgram, R.M. \& Hong, E. (1999). Creative out-of-school activities in intellectually gifted adolescents as predictors of their life accomplishment in young adults: A longitudinal study. Creativity Research Journal, 12, 77-87.

Mönks, F.J. \& Mason, E.J. (2000). Developmental psychology and giftedness: Theories and research. In F.J. Monks, \& K.A. Heller (Eds.), International handbook of giftedness and talent (2nd ed., pp.141-267). New York: Elsevier Applied Science.

Montessori, M. (1992). L'enfant [The child]. Paris, Desclée de Brouwer.

Mulhern, J.D. (2003). The gifted child in the regular classroom. Roeper Review, 25(3), $112-115$

Newton, L., and Newton, D. (2010). Creative thinking and teaching for creativity in elementary school science. Gifted and Talented International, 25(2), 111-124.

Ng, A.K. (2001). Why asians are less creative than westerners. Singapore: Prentice Hall.

Noizet, G., \& Caverni, J.P. (1978). Psychologie de l'évaluation scolaire [Psychology of school evaluation]. Paris : PUF. 
Ohuche, N. M. (1987). The ideal pupil as perceived by Nigerian (Igbo) teachers and Torrance's creative personality. Indian Journal of Applied Psychology, 24(2), 80-86.

Olszewski-Kubilius, P. (2000). The Transition from Childhood Giftedness to Adult Creative Productiveness: Psychological Characteristics and Social Supports. Roeper Review, 23(2), 65-71.

Pelpel, P. (2002). Se former pour enseigner [Learning to teach]. Paris: Dunod.

Peters, W.A.M., Grager-Loidl, H., \& Supplee, P. (2000). Underachievement in gifted children and adolescent: theory and practice. In K.A.M. Heller; R.J. Sternberg; R.F. Subotnik (Eds.), International Handbook of Giftedness and Talent (pp.609-620). Oxford: Pergamon Press.

Peyronie, H. (1999). Célestin Freinet. Pédagogie et émancipation [Célestin Freinet: Pedagogy and emancipation]. Paris : Hachette Education.

Reis, S., \& McCoach, B. (2002). Underachievement in gifted students. In M. Neihart, S. Reis, N. Robinson, \& S. Moon (Eds), The social and emotional development of gifted children (pp.81-91). Washington DC: Prufrock Press.

Renzulli, J. (1979). What makes giftedness: a reexamination of the definition of the gifted and talented. Ventura, CA: Ventura County Superintendant of Schools Office. 
Renzulli, J. (1986). The three ring conception of giftedness: a developmental model for creative productivity. In R.J. Sternberg \& J.E. Davidson (Eds.), Conception of giftedness (pp.53-92). New-York: Cambridge University Press.

Runco, M.A., \& Albert, R.S. (1986). The threshold theory regarding creativity and intelligence: An empirical test with gifted and non-gifted children. Creative Child and Adult Quarterly, 11, 212-218.

Sak, U. (2004). About Creativity, Giftedness and Teaching the Creativity Gifted in the Classroom. Roeper Review, 26(4), 216-222.

Simonton, D.K. (1984). Genius, Creativity and Leadership. Cambridge, MA: Havard University Press.

Sternberg, R.J. (1985). Beyond IQ: a triarchic theory of human intelligence. New York: Cambridge University Press.

Sternberg, R.J. (2003). Creative Thinking in the classroom. Scandinavian Journal of Educational Research, 47 (3), 325-338.

Sternberg, R., \& Lubart, T.I. (1995). Defying the Crowd: Cultivating creativity in a culture of conformity. New York: Free Press.

Strom, R. D., \& Strom, P. S. (2002). Changing the rules : Education for creative thinking. Journal of Creative Behavior, 36(3), 183-200. 
Torrance, E.P. (1968). A longitudinal examination of the fourth-grade slump in creativity. Gifted Child Quarterly, 13(3), 155-158.

Torrance, E.P. (1976). Tests de pensée créative. Paris: Editions du Centre de Psychologie Appliquée.

Vaughn, V.L., Feldhusen, J.F., \& Asher, J.W. (1991). Meta-analyses on review of research on pullout programs in gifted education. Gifted Child Quarterly, 35(2), 92-98.

Verkasalo, M., Tuomivaara, P., \& Lindeman, M. (1996). 15-year-old pupils' and their teachers' values, and their beliefs about the values of an ideal pupil. Educational Psychology, 16(1), 35-47.

Wentzel, K.R. (1993). Does being good make the grade? Social behaviour and academic competence in middle school. Journal of Educational Psychology, 85(2), 357-364.

Wintkin, H.A., \& Goodenough, D.R. (1981). Cognitive styles: essence and origins. New York: International Universities Press.

Zhang, L.-F. (2008). Preferences for teaching styles matter in academic achievement: Scientific and practical implications. Educational Psychology, 28(6), 615-625. 